\title{
DENSITAS ZOOXANTHELLAE KARANG FOLIOSE PADA KEDALAMAN BERBEDA (ZONA TERUMBU KARANG) DI PERAIRAN WAWORAHA KECAMATAN SOROPIA
}

\section{Zooxanthellae Density of Foliose Coral at Different Depth (Coral Reefs Zona) in The Waters of Waworaha Konawe District}

\author{
Resni Agustina Salim ${ }^{1}$, Ratna Diyah Palupi ${ }^{2}, \operatorname{Ira}^{3}$ \\ ${ }^{1}$ Mahasiswa Ilmu Kelautan \\ Fakultas Perikanan dan Ilmu Kelautan Universitas Halu Oleo \\ Jl. HEA Mokodompit Kampus Bumi Tridharma Anduonohu Kendari 93232 \\ ${ }^{2}$ Surel: pratna97@yahoo.com \\ ${ }^{3}$ Surel: bahari_00@yahoo.co.id
}

\begin{abstract}
Abstrak
Zooxanthellae merupakan mikroalga yang berperan penting bagi pertumbuhan karang. Penelitian ini bertujuan untuk mengetahui densitas zooxanthellae karang foliose pada 3 zona terumbu karang yang berbeda (reef flat, reef crest, reef slope) di Perairan Waworaha kecamatan soropia, Konawe. Pengambilan data telah dilakukan pada April sampai Mei 2017 melalui dua tahapan yaitu pengambilan sampel jaringan karang foliose di perairan dan perhitungan zooxanthellae di laboratorium.. Pengambilan sampel karang foliose dilakukan dengan metode koleksi bebas (free handpicking) dengan mengunakan alat SCUBA sedangkan analisisi densitas zooxanthellae dilakukan dengan metode homogenisasi. Hasil penelitian menunjukan bahwa densitas zooxanthellae karang foliose di lokasi penelitian rata-rata sebesar 5.1x $10^{6}$ $\mathrm{sel} / \mathrm{cm} 2$. Densitas zooxanthellae berdasarkan zona terumbu karang di Perairan Waworaha tercatat paling tinggi pada zona reef flat $\left(7.7 \times 10^{6} \mathrm{sel} / \mathrm{cm}^{2}\right)$ diikuti zona reef crest $\left(4.5 \times 10^{6} \mathrm{sel} / \mathrm{cm}^{2}\right)$ dan yang terendah berada pada zona reef slope (3.2 $\mathrm{x} 10^{6} \mathrm{sel} / \mathrm{cm}^{2}$ ). Perbedaan densitas zooxanthellae pada karang foliose lebih dipengaruhi oleh perbedaan intensitas cahaya.
\end{abstract}

Kata kunci : Densitas zooxanthellae, karang foliose, Perairan Waworaha, zona terumbu karang

\begin{abstract}
Zooxanthellae is a microalga that plays an important rolrto thel growth of coral. This research aims todetermine the density of foliose corals zooxanthellae on the three different zones of coral reefs (reef flat, reef crest, reef slope) in the waters of Waworaha, Soropia subdistrict, Konawe. Data retrieval was carried out in April until May 2017 through two stages: namely the sampling of foliose coral tissue sampling was carried out using a free handpicking method by the SCUBA tool while zooxanthellae density sample analysis was carried out using the homogenization method. The results showed that the density of zooxanthellae coral foliose on site research averaged of $5.1 \times 10^{6}$ cells $/ \mathrm{cm}^{2}$.Zooxanthellae densities based on zones of coral reefs in the watersof the Waworaha was recorded the highest on the reef flat zone $(7.7 \mathrm{x}$ $10^{6}$ cells $\left./ \mathrm{cm}^{2}\right)$ followed, by the zone of the reef crest $\left(4.5 \times 10^{6}\right.$ cells $\left./ \mathrm{cm}^{2}\right)$ and the lowest was at the reef slope zone $\left(3,2 \times 10^{6}\right.$ cells $\left./ \mathrm{cm}^{2}\right)$. The difference in the density of zooxanthellae on foliose corals mostly affected by differences in light intensity.
\end{abstract}

Key words: Zooxanthellae density, Foliose coral, Coral reef zone. Waworaha.

\section{Pendahuluan}

Terumbu karang merupakan ekosistem yang mempunyai produktivitas yang tinggi dan memiliki fungsi ekologis yang penting bagi kehidupan bawah laut. Beberapa fungsi ekologis dari terumbu karang yaitu sebagai tempat memijah, tempat mencari makan dan tempat hidup berbagai jenis biota laut, sehingga menjadikan ekosistem ini tinggi akan tingkat keanekaragaman hayati (Suharsono, 1996).

Komponen biotik yang tak dapat dipisahkan dari ekosistem terumbu karang adalah hewan karang. Hewan Karang masuk dalam ordo Scleraktinia yang dapat menghasilkan endapan masif berupa kalsium karbonat $\left(\mathrm{CaCo}_{3}\right)$. Proses pebentukan kalsum karbonat tidak terlepas dari peran serta alga simbion karang yakni zooxanthellae. zooxanthellae merupakan mikroalga yang hidup di dalam lapisan endoderma karang dan menjalin simbiosis mutualisme dengan hewan karang dimana kedua organism ini mengutungkan satu sama lain. Alga ini menyediakan bahan organik hingga 95\% dari total yang dibutuhkan oleh karang (Muscatine, 1990). Sedangkan karang 
memberikan tempat tinggal pada inang, tempat perlindungan dari ancaman predator, serta zooxanthellae memanfaatkan sisa-sisa metabolism dari hewan karang.

Tingkat kepadatan zooxanthellae yang terdapat di dalam karang di pengaruhi oleh beberapa faktor salah satu faktor yang sangat mempengaruhi yakni kedalaman suatu perairan. Kedalaman suatu perairan mempengaruhi besarnya intensitas cahaya matahari yang masuk ke dalam perairan dimana semakin dalam suatu perairan kemampuan cahaya matahari yang masuk akan semakin berkurang, sebagai organism autotrof zooxanthellae sangat membutuhkan cahaya matahari untuk proses fotosintesis.

Penelitian mengenai densitas zooxanthellae berdasarkan kedalaman (zona terumbu karang) telah dilakukan di beberapa daerah di ndonesia. seperti penelitian yang dilakukan Ihsan (2016) terkait studi kepadatan dan indeks mitotik zooxanthellae dari tiga life form karang Coral Branching (CB), Coral Encrusting (CE), dan Coral Foliose (CF) pada kedalaman berbeda (zona terumbu karang) di Pulau Barranglompo Kota Makassar diperoleh jumlah zooxanthellae pada $\mathrm{CF}$ paling tinggi dari dua life form yang lain. Tidak hanya pada karang penelitian zooxanthellae dilakukan pula pada kima atau kerang raksasa di Perairan Kepulauan Spermonde Ira (2004)) bahwa pada kedalaman kurang dari 2 meter tingkat kepadatan zooxanthellae mencapai $6 \times 10^{6}$ $\mathrm{sel} / \mathrm{cm}^{2}$, sedangkan pada kedalaman di atas 7 meter kepadatan zooxanthellae ditemukan hanya sekitar $0,8 \times 10^{6} \mathrm{sel} / \mathrm{cm}^{2}$. Dari beberapa penelitian tersebut menunjukan bahwa kedalaman suatu perairan memengaruhi densitas zooxanthellae yang ada di dalam karang. dari latar belakang tersebut maka dilakukanya penelitian ini dengan tujuan untuk mengetahui densitas zooxanthellae berdasarkan kedalaman yang berbedah (zona terumbu karang) di Perairan Waworaha.

\section{Bahan dan Metode}

Penelitian ini dilakukan pada bulan April-Mei 2017, bertempat di Perairan Waworaha Kecamatan Soropia, Kabupaten Konawe Sulawesi Tenggara (Gambar 1). Analisis sampel karang dilakukan di Laboratorium Optik Jurusan Biologi Fakultas Matematika dan Ilmu Pengetahuan Alam Universitas Halu Oleo.

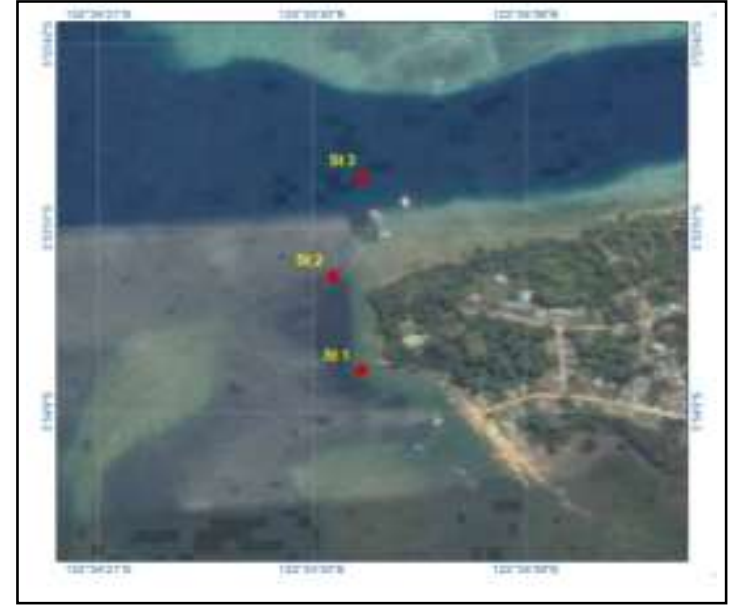

Gambar 1.Sketsa Lokasi Penelitian

Penentuan stasiun penelitian diambil berdasarkan metode purposive sampling ditetapkan sebanyak 3 stasiun yang didasarkan pada keberadaan karang foliose yang terdapat pada zona terumbu karang (reef flat, crest dan slope).

Metode pengambilan sampel pada penelitian ada 2 yaitu pengambilan data lapangan (pengambilan sampel jaringan karang) dan analisis sampel (perhitungan densitas zooxanthellae), selanjutnya diterangkan sebagai berikut:

Pengambilan sampel karang foliose dilakukan dengan menggunakan alat SCUBA (Self Contained Underwater Breathing Apparatus) dan alat bantu berupa gunting untuk memudahkan pemotongan sampel karang. Pengambilan dilakukan dengan cara mengambil dua sampel dari dua koloni karang foliose yang berbeda pada zona terumbu karang (reef flat, reef crest dan reef slope) di setiap stasiun.

Pengukuran densitas zooxanthellae dilakukan dengan metode homogenesasi (Rifa'I, 2013), zooxanthellae dipisahkan dengan inangnya dengan cara dikerik menggunakan sikat halus dengan luasan $1 \times 1$ $\mathrm{cm}$. Hasil kerikan selanjutnya disuspensikan dengan $100 \mathrm{ml}$ aquades. Pengenceran dilakukan dengan mengacu pada Ihsan (2016) yaitu dengan menggunakan air (aquades) dengan volume $100 \mathrm{ml}$ yang disaring menggunakan saringan zooxanthellae. Sampel zooxanthellae yang telah disaring dimasukkan kedalam botol sampel dan diberi lugol sebanyak 5 tetes sebagai bahan pengawet. Sampel kemudian dihitung/dicacah. Proses pencacahan 
dilakukan dengan cara meneteskan sampel zooxanthellae menggunakan pipet tetes di atas SRC (sedwick rafter counting) kemudian ditutup dengan cover glass. Setelah itu, sampel diamati di bawah mikroskop dengan perbesaran 40 kali dengan 2 kali ulangan untuk masing-masing sampel. Jumlah sampel yang dicacah sebanyak 120 kotak dari total 1000 kotak SRC. Kotak yang dicacah mewakili 40 kiri, 40 tengan, dan 40 kanan. Zooxanthellae yang terlihat kemudian dihitung dengan bantuan hand counter dan dicatat jumlahnya

Pengukuran parameter pendukung data penelitian berupa intensitas cahaya kolom perairan menggunakan lux meter, suhu permukaan menggunakan thermometer, salinitas permukaan menggunakan hand refraktometer, kecerahan menggunakan secchi disk, kedalaman mengunakan deep gauge dan kecepatan arus permukaan menggunakan layangan arus. Pengukuran kondisi oseanografi dilakukan pada tiap-tiap stasiun penelitian.

Kepadatan sel zooxanthellae diperoleh dengan menggunakan rumus APHA (1992) yang dimodifikasi oleh Niartiningsih (2001) yaitu sebagai berikut:

$\mathrm{D}=\frac{N \times A t \times V t}{A c \times V s \times A s}$

Keterangan :

$\mathrm{D}=$ densitas zooxanthellae $\left(\mathrm{sel} / \mathrm{cm}^{2}\right)$

$\mathrm{N}=$ jumlah zooxanthellae yang dihitung (sel)

At $=$ luas cover glass

$\mathrm{Vt}=$ volume total sampel awal $(\mathrm{ml})$

$\mathrm{Ac}=$ luas sampel yang dikerik $\left(\mathrm{cm}^{2}\right)$

$\mathrm{Vs}=$ volume sampel yang digunakan $(\mathrm{ml})$

As $=$ luas amatan

Intensitas cahaya yang berada dalam

kolom perairan diperoleh menggunakan koefisien peredupan yang didasarkan pada hukum Lambert-Beer Cole (1988) yaitu sebagai berikut:

$\mathrm{Iz}=$ Io $\mathrm{e}^{-k z}$

$\mathrm{k}=0,191+\left(\frac{1,241}{\text { Zsd }}\right)$

Keterangan :

$\mathrm{Iz}=$ intensitas cahaya pada suatu kedalaman

$\mathrm{Z}$

Io $=$ intensitas cahaya pada permukaan perairan

$\mathrm{e}=$ bilangan dasar logaritma $(2,718)$

$\mathrm{k}=$ koefisien peredupan

$\mathrm{z}=$ kedalaman

$\mathrm{Z}_{\mathrm{sd}}=$ kedalaman secchi disk

\section{Hasil dan Pembahasan}

Hasil penelitian yang telah dilakukan diperoleh hasil bahwa densitas zooxanthellae di zona terumbu karang tertinggi terdapat pada zona reefflat dengan rata-rata densitas kurang lebih sebesar 7,7 x $10^{6} \mathrm{sel} / \mathrm{cm}^{2}$ dan densitas terendah terdapat pada zona reef slope dengan rata-rata densitas kurang lebih sebesar $3,2 \times 10^{6} \mathrm{sel} / \mathrm{cm}^{2}$.

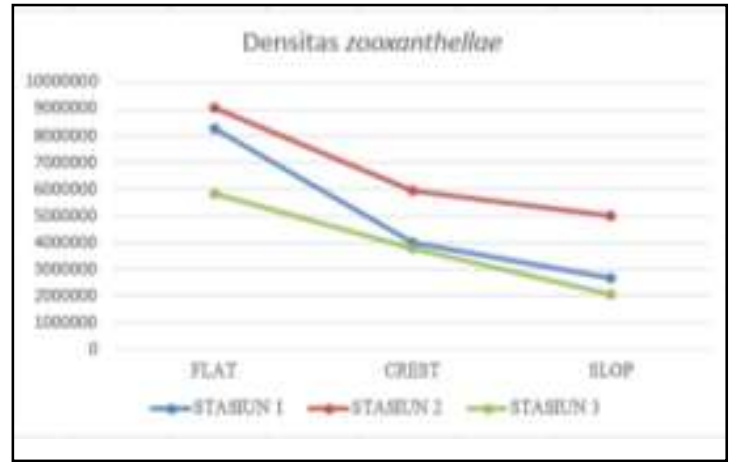

Gambar 2. Kurva densitas zooxanthellae karang foliose yang ada pada zona terumbu karang

Berdasarkan zona terumbu karang densitas zooxanthellae tertinggi berada pada zona reef flat, rata-rata sebesar $7,7 \times 10^{6}$ $\mathrm{sel} / \mathrm{cm}^{2}$. Tingginya jumlah zooxanthellae pada zona ini dikarenakan kedalaman pengambilan sampel untuk zona ini mencapai 3-4 m, kedalaman tersebut sangat mempengaruhi tingkat kecerahan perairan yang tinggi dan besarnya intensitas cahaya yang masuk, untuk nilai intensitas cahaya pada zona ini rata-rata sebesar 5982,03 lux. Kedalaman yang lebih dangkal akan menyebabkan cahaya akan masuk lebih ban yak ke perairan dan mencapai lebih banyak ke karang. Banyaknya jumlah cahaya akan mempengaruhi jumlah zooxanthellae karena zooxanthellae memerlukan cahaya untuk dapat hidup.

Zona reef crest memiliki rata-rata densitas zooxanthellae sebanyak 4,5 x $10^{6}$ $\mathrm{sel} / \mathrm{cm}^{2}$ (Tabel 2). Setiap bertambahnya kedalaman maka densitas zooxanthellae semakin berkurang begitu pula yang terjadi pada zona ini. Kedalaman pada zona ini mencapai 5-6 m. Nilai intensitas cahaya pada zona ini rata-rata sebesar 2045,97 lux. Jika dibandingkan dengan penelitian yang dilakukan Asmiati (2016) diperoleh hasil bahwa densitas zooxanthellae di kedalaman 5 meter rata-rata mencapai 
$1,40 \times 10^{6} \mathrm{sel} / \mathrm{cm}^{2}$ dengan nilai intensitas cahaya mencapai 870 lux, dari hasil tersebut dapat dilihat bahwa nilai intensitas cahaya yang jauh berbedah berpengaruh besar terhadap densitas zooxanthellae yang ada pada karang sebab sebagai organisme autrotof zooxanthellae sangat membutukan cahaya matahari untuk proses fotosintesis.

Hasil perhitungan densitas zooxanthellae untuk zona reef slope berkisar $2.0 \times 10^{6}-5.8 \times 10^{6} \mathrm{sel} / \mathrm{cm}^{2}$ (Tabel 2) dengan kisaran rata-rata $3.8 \times 10^{6} \mathrm{sel} / \mathrm{cm}^{2}$ jumlah ini paling rendah dibandingkan zona lainnya. Kedalaman pada zona ini yakni berkisar 10$12 \mathrm{~m}$ (Tabel 4). Kedalaman tersebut menyebabkan intensitas cahaya semakin berkurang yakni mencapai 156,67 lux.

Berdasarkan Gambar 3. dari semua stasiun penelitian densitas zooxanthellae pada stasiun II menunjukkan nilai yang lebih tinggi dibanding stasiun yang lainnya. Densitas zooxanthellae di stasiun penelitian dapat dilihat pada Gambar 3.

Berdasarkan Gambar 3 stasiun yang memiliki densitas terendah ialah stasiun III dengan rata-rata sebesar $3,8 \times 10^{6} \mathrm{sel} / \mathrm{cm}^{2}$. Stasiun III memiliki densitas yang terendah dibanding stasiun yang lain baik pada zona reef flat, reef crest dan reef slope. Stasiun III terletak berhadapan langsung dengan laut lepas sehingga arus pada stasiun ini paling tinggi dibanding stasiun lainnya yakni sebesar $0,21 \mathrm{~m} /$ det. Tingginya arus di stasiun ini menyebabkan nilai kecerahan menjadi rendah yakni hanya mencapai 2,75 m. Kecerahan yang rendah disebabkan oleh pengadukan oleh arus sehingga butiran substrat yang ada distasiun III terangkat dan melayang-layang di kolom perairan akibatnya nilai kecerahan menjadi rendah. Rendahnya nilai kecerahan di stasiun ini membuat nilai intensitas cahaya yang masuk juga menjadi lebih rendah yakni sebesar 1009.81 lux.

Densitas zooxanthellae yang diperoleh pada stasiun II rata-rata mencapai $6.6 \times 10^{6} \mathrm{sel} / \mathrm{cm}^{2}$ (Tabel 2). Hasil ini menunjukan stasiun II memiliki densitas tertinggi baik pada zona reef flat, reef crest dan reef slope dibandingkan stasiun lainnya. Jika densitas zooxanthellae tinggi disuatu karang maka efisiensi pertumbuhan karang akan semakin baik karena zooxanthellae berperan dalam menyediakan bahan organik hingga $95 \%$ dari total yang dibutuhkan oleh karang. Berdasarkan Alamin (2017) tutupan karang yang ada di lokasi penelitian (stasiun II) menunjukan nilai $70,18 \%$. Nilai tersebut termasuk dalam kategori baik berdasarkan kriteria penentuan kondisi terumbu karang mengenai Keputusan Mentri Negara Lingkungan Hidup Nomor 04 Tahun 2004. Dari hasil tersebut dapat diketahui bahwa karang yang ada di stasiun II kondisi pertumbuhan masih dalam kondisi baik dengan ditandai tingginya densitas zooxanthellae yang ada di stasiun II.

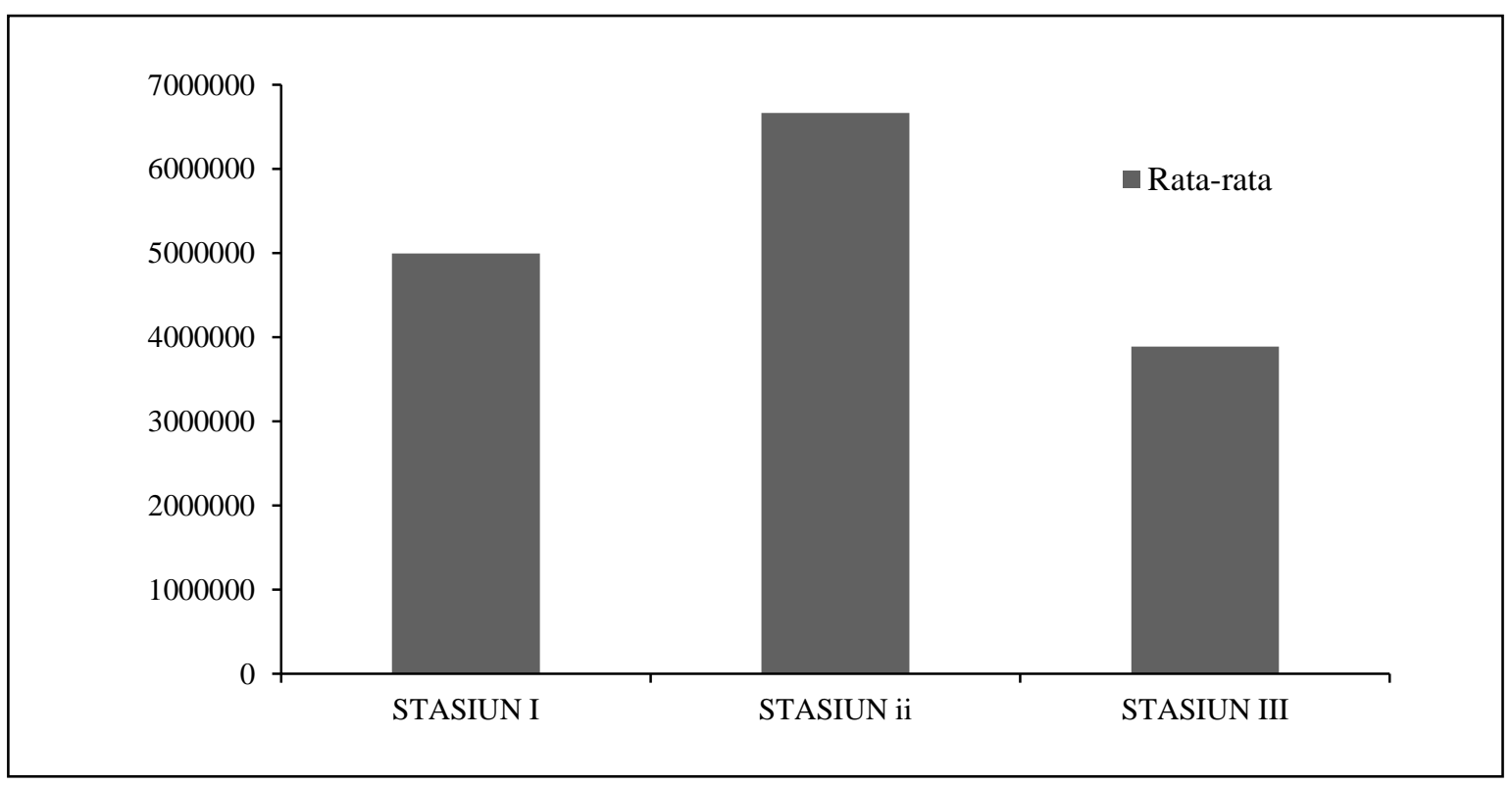

Gambar 3. Grafik Densitas Zooxanthellae di Lokasi Penelitian. 
Tabel 3. Parameter Fisik Kimia di lokasi penelitan

\begin{tabular}{ccccccc}
\hline Stasiun & $\begin{array}{c}\text { Intensitas } \\
\text { Cahaya (klux) }\end{array}$ & $\begin{array}{c}\text { Suhu } \\
\left({ }^{\mathbf{}} \mathbf{C}\right)\end{array}$ & $\begin{array}{c}\text { Salinitas } \\
(\mathbf{p p t})\end{array}$ & $\begin{array}{c}\text { Kecerahan } \\
(\mathbf{m})\end{array}$ & $\begin{array}{c}\text { Kecepatan } \\
\text { Arus }(\mathbf{m} / \mathbf{d e t})\end{array}$ & $\begin{array}{c}\text { Kedalaman } \\
(\mathbf{m})\end{array}$ \\
\hline I & 0,87 & 28,5 & 23,0 & 0,8 & 0,03 & 5,0 \\
II & 51,04 & 29,0 & 26,0 & 2,0 & 0,05 & 2,0 \\
\hline
\end{tabular}

Stasiun I memiliki densitas zooxanthellae sebesar 4,9 x $10^{6} \mathrm{sel} / \mathrm{cm}^{2}$ dengan rata-rata densitas mencapai $2,6 \times 10^{6}$ $8,2 \times 10^{6} \mathrm{sel} / \mathrm{cm}^{2}$. Jumlah densitas zooxanthellae di stasiun I berada diurutan kedua baik pada zona reef flat, reef crest dan reef slope. Stasiun I terletak didekat pemukiman masyarakat jadi masukan sedimentasi yang ada di darat lebih berdampak langsung ke stasiun ini. Berdasarkan Rosdiana (2017) tipe substrat untuk stasiun I yakni pasir berlempung dengan 11,84\% debu dengan demikian jika terjadi pengadukan membuat material sedimen akan tinggi dikolom perairan sehingga menyebabkan kecerahan yang rendah dan partikel sedimen yang melayanglayang dikolom air tersebut akan menutupi polip karang akibabnya pertumbuhan karang akan terganggu sehingga berdampak pada densitas zooxanthellae.

Nilai kecepatan arus stasiun I mencapai $0,11 \mathrm{~m} /$ det arus di stasiun ini paling rendah hal ini disebabkan karena letak stasiun I berada di dalam teluk. Rendahnya arus di stasiun I menyebabkan karang akan lebih memerlukan banyak energi untuk membersihkan partikel sedimen yang terperangkap di polipnya. Akibatnya energi yang seharusnya digunakan untuk tumbuh dan berkembang digunakan untuk membersihkan polip sehingga pertumbuhannya menjadi lambat. Lambatnya pertumbuhan karang pada stasiun ini dapat dilihat pada nilai tutupan karang yang ada dilokasi ini. Berdasarkan Alamin (2017) tutupan karang dilokasi penelitian (stasiun I) yakni 66,91\%. Nilai tersebut menunjukan nilai tutupan karang lebih rendah jika dibandingkan stasiun II yang memiliki nilai tutupan karang yang tinggi dan densitas yang tinggi pula. Nilai suhu dan salinitas pada stasiun ini mencapai suhu $25-29{ }^{\circ} \mathrm{C}$,salinitas $26-29$ ppt. Nilai suhu dan salinitas tersebut masih tergolong optimum untuk pertumbuhan karang.

Rata-rata densitas zooxanthellae jika dibandingkan antar stasiun penelitian, stasiun II lebih rendah $\left(0,70 \times 10^{6} \mathrm{sel} / \mathrm{cm}^{2}\right)$. Hal ini tidak terlepas dari kondisi lingkungan yang berpengaruh terhadap kehidupan karang dan alga zooxanthellae yakni pengaruh faktor fisik perairan yaitu suhu. Stasiun II memiliki suhu di luar ambang batas toleransi oleh zooxanthellae yaitu $29{ }^{\circ} \mathrm{C}$ (Tabel 3). Suhu tersebut berdampak pada pemutihan karang (bleaching).

Karang di stasiun II banyak terkena bleaching. Sesuai pernyataan Manuputty (2008) bahwa zooxanthellae dapat tumbuh optimum pada suhu $26-28{ }^{\circ} \mathrm{C}$, dengan nilai suhu yang ada di lokasi penelitian menunjukkan bahwa dapat mempengaruhi zooxanthellae sebagai alga simbion karang. Naiknya suhu walaupun hanya satu atau dua derajat saja dapat berpengaruh terhadap konsentrasi zooxanthellae di dalam jaringan karang. Bila kenaikan suhu terlalu tinggi, jaringan karang akan mengerut, dan zooxanthellae akan keluar ke air laut. Akibat keluarnya zooxanthellae, pigmen pada karang memudar hingga koloni karang menjadi warna putih. Proses ini dikenal dengan "bleaching". Kejadian ini terjadi secara besarbesaran pada tahun 1998 dan kesempatan untuk bertahan hidup pada waktu itu bervariasi pada masing-masing jenis. Parameter fisik kimia di lokasi penelitian dapat dilihat pada Tabel 3.

Fenomena bleaching yang terjadi sebagian besar dipengaruhi oleh peristiwa el-nino di Indonesia yang terjadi pada Tahun 2015 dimana terjadinya peningkatan suhu secara drastis yang tidak dapat ditolerir karang dan alga simbion zooxanthellae. Berdasarkan data BMKG (Badan Meteorologi, Klimatologi, dan Geofisika) tahun 2016 rata-rata kenaikan suhu muka laut tahun 2015-2016 sebesar $2{ }^{\circ} \mathrm{C}$ yang berdampak pada pemutihan karang (bleaching) di lokasi penelitian. Kenaikan suhu tersebut berdampak nyata pada pemutihan karang (bleaching) khususnya di stasiun II pada kedalaman $2 \mathrm{~m}$ (Tabel 3). Kondisi ini tidak sama dengan stasiun I, dimana karang ditemukan pada kedalaman 5 m. Kedalaman di bawah permukaan paling rentan terhadap pengaruh akibat peningkatan 
suhu sehingga memicu keluarnya zooxanthellae dari jaringan karang. Seperti yang dijelaskan Shu et al. (2011) bahwa karang yang terkena bleaching utamanya pada kedalaman kurang dari $5 \mathrm{~m}$. Kaitannya dengan kenaikan suhu permukaan laut hal senada dikatakan Jones et al. (1998) bahwa dalam kasus tekanan termal, kenaikan suhu mengganggu kemampuan zooxanthellae untuk berfotosintesis dan dapat memicu produksi kimiawi berbahaya yang merusak sel-sel mereka.

\section{Simpulan}

1. Hasil penelitian yang diperoleh rata-rata densitas zooxanthellae karang foliose yang ditemukan di lokasi penelitian sebesar 5,1 x $10^{6} \mathrm{sel} / \mathrm{cm}^{2}$ dengan kisaran nilai rata-rata $3,8 \times 10^{6}-6,6 \times 10^{6} \mathrm{sel} / \mathrm{cm}^{2}$

2. Densitas zooxanthellae karang foliose berdasarkan zona terumbu karang untuk densitas tertinggi berada pada zona reef flat dan densitas terendah berada pada zona reef slope.

3. Densitas berdasarkan stasiun penelitian tertinggi berada pada stasiun II disusul stasiun I dan stasiun III.

\section{Daftar Pustaka}

Asmiati, 2017. Densitas zooxanthellae berdasarkan bentuk pertumbuhan karang di perairan Kessilampe dan Bungkutoko, Kendari. Skripsi. Program sarjana Universitas Halu Oleo. Kendari

Ira. 2004. Studi Kepadatan Zooxanthellae Yang Berasosiasi Dengan Kima (Tridacnidae) Di Perairan Kepulauan Spermonde. Skripsi Universitas Hasanuddin, Makassar. Makassar Provinsi Sulawesi Selatan. Tesis Institut Pertanian Bogor. Bogor.

Jones RJ. 1997. Zooxanthellae loss as bioassay for assesssing stress in corals. Mar Ecol Prog Ser 149:163-171

Muscatine L. 1990. The role of symbiotic algae in carbon and energy flux in reef coral. in: Dubinsky Z. (Ed). Coral reefs ecosystem in the world. Elsevier. Amsterdam.

Niartiningsih, A. 2001. Analisis Mutu Zooxanthellae dari Berbagai Inang dan Pengaruhnya terhadap Sintasan dan Pertumbuhan Juvenil Kima Sisik
(Tridacna squamosa). Disertasi Pascasarjana FIKP Unhas. Makassar

Ofri, 2014. Densitas zooxanthellae dan kandungan klorofil-a pada karang lunak di Pulau Hari, Moramo. Skripsi. Program sarjana Universitas Halu Oleo. Kendari

Pudjiarto, R.K dan widiarti, R. 2015. Kelimpahan zooxanthellae pada koloni karang Montipora yang Terinferi Black Band Disease dan White Syndrome di Pulau Air, Kepulauan Seribu. Prosiding, FIKP Univwersitas Hasanudding, Makassar.

Rifa'i, M. A. 2013. Indeks Mitotik Simbion Alga Zooxanthellae Pada Anemon Laut Stlchodactyla gigantean Hasil Reproduksi Aseksual. Jurnal Universitas Lambung Mangkurat, Banjarbaru. Banjarbaru

Suharsono. 2004. Jenis-Jenis Karang di Indonesia. Pusat Penelitian Oseanografi -LIPI.

Zamani Brown. 1992. Mitotic Indice of Zooxanthellae : a Comparasion of Based on Nuclear and Sell Division Frequencies, Marine Ecology Progress Series. Newcastle.

Shu, L., Ke, F. Y, Tian, R. C, Qi, S, Hui, L. Zhang. 2011. Assesment of coral bleaching using symbiotic zooxanthellae density and satellite remote sensing data in the Nansha Islands, South China Sea. Chinesse Sci Bull, 56: 1031-1037, doi: 10. 1007/s11434-011-9390-6.

Zamani \& Brown. 1992. Mitotic Indice of Zooxanthellae: a Comparasion of Techniques Based on Nuclear and Sell Division Frequencies. Marine Ecology Progress Series. Newcastle. 